\title{
地球の表面と真空
}

\author{
佐藤智重 ${ }^{1, *}$. 久保利隆 ${ }^{2}$

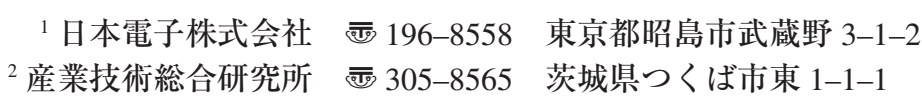

(2020 年 1 月 24 日受付；2020 年 1 月 27 日掲載決定)

\section{Earth Surface and Space Vacuum}

Tomoshige $\mathrm{SATO}^{1, *}$ and Toshitaka KuBO ${ }^{2}$

${ }^{1}$ JEOL Ltd., 3-1-2 Musashino, Akishima, Tokyo 196-8558

${ }^{2}$ AIST, Tsukuba Central 5, 1-1-1 Higashi, Tsukuba, Ibaraki 305-8565

(Received January 24, 2020 ; Accepted January 27, 2020)

\begin{abstract}
To celebrating the 2nd anniversary of The Japan Society of Vacuum and Surface Science (JVSS), we will feature the surface of the earth and vacuum. Contributions include topics on our environment of the land and ocean, the altitude atmosphere, two Hayabusa space development reports and space weathering. There may be new tips for our study of surface vacuum from the large earth environment.
\end{abstract}

KEYWORDS : earth, ocean, surface, vacuum, Hayabusa

日本表面真空学会は令和 2 年 4 月に, 日本表面科学会 と日本真空学会の二つの学会が合併して 2 周年を迎えま した。この統合を祝う今回の特集号では「表面と真空」 を大きく扱った話題を紹介します。我々が住む地球の表 面から宇宙に至る真空について (Fig. 1), 専門分野の研 究者の方々に執筆して頂きました。

まずは, 大きな地球の表面【土壤】と【海洋と大気の 相互作用】として, 我々が日常経験している環境からの 報告です。次に,【大気と高度大気】として真空の宇宙 につながります。真空では【人工衛星から見る地球】と した大きな地球環境を観る話題があります。そして, 我 が国の【宇宙】研究として素晴らしい実績を上げた小惑 星探査機「はやぶさ」のマイクロ波イオンエンジンの動 作原理の紹介, さらに地球への帰還を目指している「は やぶさ2」は真空技術を利用した誇らしい話題でしょ う。また, 太陽系科学についても話題を提供して頂いて おります。最後に，【宇宙風化】につながり，月と小惑 星が宇宙風化していく話題についても寄稿して頂きまし た。

\footnotetext{
*E-mail : tosato@jeol.co.jp
}

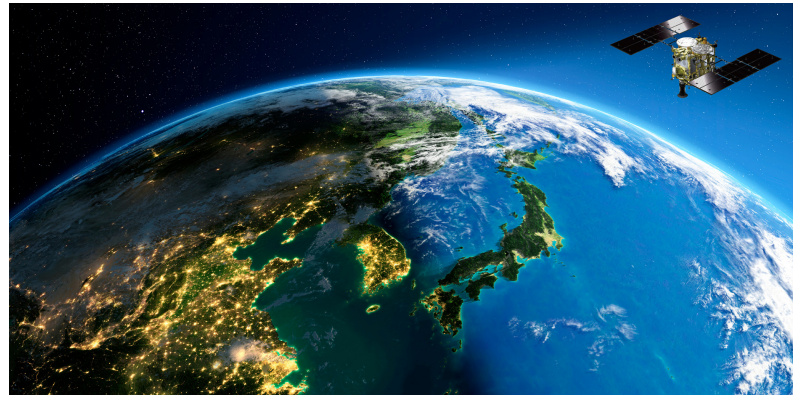

Fig. 1. (color online). Earth environment on the land and ocean surface. Spacecraft Hayabusa2 explores in vacuum space. (Includes JAXA copyright image.)

このような広い視野で観た地球環境の表面と真空を考 えると, 我々の研究分野である薄膜表面や真空技術の研 究において, 何らかの新しいヒントがあるかも知れませ ん。

この特集号は, 学術振興委員会 141 委員会（マイクロ ビームアナリシス）の平成 29 年研究会で講演された方 に執筆して頂きました。心よりお礼申し上げます。 